\title{
HUBUNGAN EFIKASI DIRI DENGAN PENGAMBILAN KEPUTUSAN KARIR PADA MAHASISWA TINGKAT AKHIR FAKULTAS PSIKOLOGI UNIVERSITAS MERCU BUANA YOGYAKARTA
}

\author{
Ros Patriani Dewi \\ Universitas Mercu Buana Yogyakarta \\ yosie.patriani@gmail.com
}

\begin{abstract}
Abstrak
Penelitian ini bertujuan untuk melihat hubungan antara Efikasi Diri dengan Pengambilan Keputusan Karir pada Mahasiswa Tingkat Akhir Fakultas Psikologi Universitas Mercu Buana Yogyakarta (UMBY). Subjek penelitian adalah 50 mahasiswa tingkat akhir (angkatan 2014) Fakultas Psikologi UMBY. Hipotesis yang diajukan dalam penelitian ini yaitu ada hubungan yang positif antara Efikasi Diri dengan Pengambilan Keputusan Karir pada mahasiswa tingkat akhir Fakultas Psikologi. Alat ukur dalam penelitian ini menggunakan Skala Efikasi Diri dan Skala Pengambilan Keputusan Karir. Hasil penelitian menunjukkan hasil korelasi $\mathrm{r}_{\mathrm{xy}} 0,357(\mathrm{p}<0,05)$. Hasil ini menunjukkan adanya hubungan positif antara Efikasi Diri dengan Pengambilan Keputusan Karir pada mahasiswa tingkat akhir Fakultas Psikologi UMBY. Sumbangan efektif Efikasi Diri terhadap Pengambilan Keputusan Karir sebesar 12,8\%, sisanya dipengaruhi faktor-faktor lain sebesar $87,2 \%$.
\end{abstract}

Kata kunci: Efikasi Diri, Pengambilan Keputusan Karir

\section{THE RELATIONSHIP BETWEEN SELF-EFFICACY AND CAREER DECISION MAKING IN FINAL LEVEL STUDENTS FACULTY OF PSYCHOLOGY, MERCU BUANA YOGYAKARTA UNIVERSITY}

\author{
Ros Patriani Dewi \\ Universitas Mercu Buana Yogyakarta \\ yosie.patriani@gmail.com
}

\begin{abstract}
This study aims to see the relationship between Self-Efficacy and Career Decision Making at the Final Level Students of the UMBY Psychology Faculty. The research subjects were 50 final year students (class of 2014) Faculty of Psychology, Mercu Buana University, Yogyakarta. The hypothesis proposed in this study is that there is a positive relationship between Self-Efficacy and Career Decision Making in the final year students of the Faculty of Psychology UMBY. The measuring instrument in this study uses the SelfEfficacy Scale and Career Decision Scale. The results of the study showed that the rxy correlation was 0.357 ( $\mathrm{p}<0.05$ ). These results indicate a positive relationship between Self-Efficacy and Career Decision Making in the final year students of the UMBY Psychology Faculty. Effective contribution of SelfEfficacy to Career Decision Making is $12.8 \%$, the rest is influenced by other factors by $87.2 \%$.
\end{abstract}

Kata Kunci : Self Efficacy, Career Decision Making 
PENDAHULUAN

Karir adalah salah satu tahap yang berpengaruh pada hidup manusia secara keseluruhan. Oleh karenanya ketepatan memilih serta menentukan keputusan karir menjadi titik penting dalam perjalanan hidup manusia. Sebelum ia masuk ke dalam dunia kerja maka ia harus melewati serangkaian proses karir, dimana proses karir tersebut dimulai sejak seseorang duduk di bangku Sekolah Dasar (SD) sampai ia masuk dalam jenjang Perguruan Tinggi (PT).

Mulai dari Sekolah Dasar (SD), Sekolah Menengah Pertama (SMP) dan Sekolah Menengah Atas (SMA), siswa sudah mengetahui dan sudah dihadapkan pada pilihan-pilihan karir, hanya saja mereka dalam pemilihan karir masih mengikuti apa yang mereka inginkan saat ini. Sedangkan untuk mahasiswa yang menempuh pendidikan di Perguruan Tinggi (PT) sudah harus dituntut untuk menentuan pilihan karirnya guna kelangsungan hidupnya di masa depan. Seorang mahasiswa sudah tidak lagi berada pada fase fantasi dan tentatif seperti anak usia Sekolah Dasar (SD) sampai anak usia Sekolah Menengah Atas (SMA), akan tetapi mahasiswa sudah berada pada fase realistik dimana seseorang mulai aktif dalam proses seleksi pilihan karir untuk mencapai puncak 15 tahun kemudian (Ebtanastiti dan Muis, 2014).

Menurut Ginzberg (dalam Santrock 2007), perubahan cara berfikir yang subjektif menjadi pemilihan karir realistik terjadi pada sekitar usia 17 sampai 18 tahun. Periode 17 sampai 18 menuju awal usia 20-an disebut Ginzberg fase realistik dari pemilihan karir. Pada fase ini individu mengeksplorasi lebih luas karir yang ada, kemudian memfokuskan diri pada karir tertentu dan akhirnya memilih pekerjaan tertentu dalam karir tersebut. Periode usia 17 tahun sampai 18 tahun menuju awal usia 20-an adalah usia seseorang mulai masuk ke dalam jenjang Perguruan Tinggi (PT) yang pastinya akan menjadi mahasiswa. Seorang mahasiswa dalam menentukan pilihan karirnya tidak akan asal memilih, akan tetapi mereka akan lebih mempertimbangkan kembali pilihan karirnya. Tidak menutup kemungkinan dengan adanya faktor-faktor yang berasal dari dalam dirinya sendiri dan juga faktor dari luar dirinya turut mempengaruhi pilihan karir mereka.

Salah satu lembaga pendidikan formal yang menyiapkan lulusannya untuk 
memiliki keunggulan di dunia kerja adalah universitas atau perguruan tinggi. Peserta didik pada tingkat ini disebut mahasiswa. Pada tingkat akhir, mahasiswa diharapkan telah mampu mandiri dan mampu mengambil keputusan sendiri terutama berkenaan dengan dirinya. Salah satu tugas perkembangan yang dilalui oleh mahasiswa di akhir pendidikannya yaitu mahasiswa mampu melakukan pengambilan keputusan dalam menentukan pilihan karirnya.

Pada dasarnya, mahasiswa di Perguruan Tinggi (PT) sudah dikelompokkan sesuai dengan jurusanjurusan yang lebih spesifik lagi dalam bidang tertentu. Mereka memasuki jurusan tersebut guna untuk memperdalam ilmu pengetahuan dan kemampuannya, untuk mengejar karir yang akan dipilihnya setelah menyelesaikan pendidikan di Perguruan Tinggi (PT). Tetapi tidak menutup kemungkinan bahwa seseorang akan memilih karir yang tidak sesuai dengan jurusan yang sedang ditempuh saat ini. Hal ini dapat dipengaruhi oleh beberapa faktor seperti faktor keluarga, faktor lingkungan sekitar, dan lain sebagainya (Ebtanastiti dan Muis, 2014).

Pengambilan keputusan karir menjadi sangat penting karena menentukan berhasil atau tidak mahasiswa di masa depan. Berbagai penelitian yang telah dilakukan selalu konsisten menunjukkan bahwa para peserta didik yang telah membuat pilihan karir masa depan memiliki kualitas hidup yang lebih baik daripada yang belum memutuskan. Terdapat fakta yang menyebutkan bahawa tidak semua mahasiswa semester akhir dapat melakukan pengambilan keputusan karirnya. Penelitian di Universitas Padjajaran (Hami, Hinduan \& Sulistiana, 2006) menunjukkan bahwa 52,8 \% mahasiswa tingkat akhir belum mencapai kematangan karir yaitu secara umum masih berada pada taraf belum siap dalam menentukan pilihan karirnya. Hasil wawancara peneliti terhadap enam mahasiswa Fakultas Psikologi Universitas Mercu Buana Yogyakarta, yaitu tiga mahasiswa menjawab belum tahu ketika ditanya setelah lulus kuliah akan melanjutkan pendidikannya atau bekerja dimana. Dua orang mahasiswa menjawab masih bingung, merasa belum mampu karena merasa kemampuannya terbatas, dan satu orang mahasiswa berpendapat bahwa mencari pekerjaan tidak harus sesuai dengan pendidikan yang ditempuhnya. 
Data statistik pada Biro Pusat Statistik (Badan Pusat Statistik Republik Indonesia, 2017) menunjukkan data jumlah pengangguran terbuka pada Februari 2017 (open unemployement) di tanah air sebanyak 7,01 juta jiwa dimana sebanyak 5,33\% (373.100 jiwa) adalah tamatan universitas. Berdasarkan data tersebut, angka menunjukkan bahwa pengangguran untuk lulusan universitas masih tergolong tinggi dan dapat menunjukkan indikasi bahwa terdapat suatu masalah dalam pengambilan keputusan karir pada lulusan universitas.

Menurut teori Shertzer dan Stone (Winkell \& Hastuti, 2004) disebutkan bahwa dalam memutuskan sebuah karir akan selalu berkaitan dengan dua faktor, yaitu faktor internal dan faktor eksternal. Faktor internal dipengaruhi oleh nilai-nilai kehidupan, inteligensi, bakat, minat, sifat, kepribadian, pengetahuan, dan keadaan fisik. Sedangkan faktor eksternal diantaranya dipengaruhi oleh pendidikan sekolah, pergaulan teman sebaya, dan masyarakat.

Efikasi diri merupakan kepercayaan seseorang atas kemampuan dirinya untuk menyelesaikan suatu pekerjaan. Efikasi Diri dapat berfungsi sebagai penentu beberapa hal, yaitu tingkah laku, pengeluaran dan ketekunan usaha serta pola pikir dan reaksi emosional. Efikasi Diri menentukan pemilihan tingkah laku atau aktivitas yang dilakukan individu. Individu cenderung menghindari tugas dan situasi yang dipersepsi melebihi kemampuannya. Sebaliknya, individu akan dengan yakin melaksanakan dan melakukan aktivitas yang dinilai mampu untuk dilakukannya (Ormrod, 2009).

Terry menyatakan bahwa pengambilan keputusan adalah pemilihan alternatif perilaku dari dua alternatif atau lebih. Pengambilan keputusan tersebut merupakan sebuah kegiatan untuk mendapatkan suatu kepuasan dalam hidup Pengambilan keputusan dapat dianggap sebagai suatu hasil proses mental atau kognitif yang membawa pada pemilihan suatu jalur tindakan diantara beberapa alternatif yang tersedia. Setiap proses pengambilan keputusan selalu menghasilkan suatu pilihan akhir. Pengambilan keputusan merupakan suatu kegiatan yang dilakukan dengan sengaja, tidak secara kebetulan, dan tidak boleh sembarangan (Syamsi, 2000).

Esensi dari sebuah pengambilan keputusan adalah proses penentuan pilihan (Sharf, 2006). Secara alami, manusia akan diperhadapkan kepada berbagai pilihan 
dan secara alami juga ia dilatih mengambil keputusan dari pilihan-pilihan hidup yang dialaminya. Oleh karena itu, sesungguhnya manusia akan terus menerus menentukan pilihan hidup dari waktu ke waktu sampai akhir kehidupan. Proses inilah yang disebut dengan pengambilan keputusan (Sharf, 2006). Jadi, esensi dari sebuah pengambilan keputusan adalah proses penentuan pilihan. Hanya saja pada kenyataannya ada individu yang mampu dengan tepat mengambil keputusan ada juga yang tidak mampu.

Berdasarkan uraian mengenai teori Sharf di atas, maka dapat dikatakan bahwa pengambilan keputusan karir adalah proses penentuan pilihan karir. Mengantisipasi sebuah pilihan merupakan proses mengarahkan individu pada suatu pilihan yang tepat. Tiedeman (Sharf, 2006) mengemukakan bahwa keputusan untuk memilih pekerjaan, jabatan atau karir tertentu merupakan suatu rentetan akibat dari keputusan-keputusan yang dibuat individu pada tahap-tahap kehidupannya di masa lalu.

Tiedeman dan O’Hara (Sharf, 2006) membagi antisipasi dalam membuat keputusan karir menjadi empat proses, yaitu eksplorasi, kristalisasi, pemilihan, dan klarifikasi. Tiedeman menegaskan bahwa tahapan tersebut sebagai panduan (guideline) dalam mengantisipasi suatu keputusan.

a. Eksplorasi. Eksplorasi yang dimaksud adalah penjelajahan terhadap kemungkinan alternatif keputusan yang akan diambil. Melalui eksplorasi ini, individu mengetahui dengan jelas konsekuensi apa yang akan dialami jika mengambil keputusannya tersebut.

b. Kristalisasi. Tiedeman dan O'Hara (Sharf, 2006) berasumsi bahwa kristalisasi merupakan sebuah stabilisasi dari representasi berpikir. Pada tahap ini, pemikiran dan perasaan mulai terpadu dan teratur. Keyakinan atas pilihan yang akan diambil menguat. Definisi tentang alternatif pilihan semakin jelas.

c. Pemilihan. Sama halnya dengan perkembangan kristalisasi, proses pemilihan pun terjadi. Masalahmasalah individu berorientasi kepada tujuan yang relevan, yaitu individu mulai mengorganisir dalam melengkapi dan menyesuaikan terhadap berbagai pilihan karir masa depan. Sehingga pada tahap ini individu percaya atas pilihannya. 
d. Klarifikasi Ketika seorang induvidu membuat keputusan lalu melakukannya, mungkin dalam perjalanannya ada yang lancar mungkin ada yang mempertanyakan kembali karena kebingungan. Pada saat individu mengalami kebingungan, seharusnya individu tersebut melakukan eksplorasi kembali, kristalisasi, lalu melakukan pemilihan alternatif kembali dan seterusnya.

Efikasi Diri merupakan konstruk yang diajukan Bandura yang berdasarkan teori sosial kognitif. Dalam teorinya, Bandura menyatakan bahwa tindakan manusia merupakan suatu hubungan yang timbal balik antara individu, lingkungan, dan perilaku (triadic reciprocal causation). Teori Efikasi Diri merupakan komponen penting pada teori kognitif sosial yang umum, dimana dikatakan bahwa perilaku individu, lingkungan, dan faktor-faktor kognitif (misalnya, pengharapanpengharapan terhadap hasil dan Efikasi Diri) memiliki saling keterkaitan yang tinggi. Bandura mengartikan Efikasi Diri sebagai kemampuan pertimbangan yang dimiliki seseorang untuk melaksanakan pola perilaku tertentu (Bandura, 1997).

Bandura (2002) mendefinisikan Efikasi Diri sebagai keyakinan manusia pada kemampuan mereka untuk melatih sejumlah ukuran pengendalian terhadap fungsi diri mereka dan kejadian-kejadian di lingkunganya, dan ia juga yakin kalau efikasi diri adalah fondasi keagenan manusia. Selanjutnya dikatakan bahwa Efikasi Diri memiliki peran utama dalam proses pengaturan melalui motivasi individu dan pencapaian kerja yang sudah ditetapkan. Pertimbangan dalam Efikasi Diri juga menentukan bagaimana usaha yang dilakukan orang dalam melaksanakan tugasnya dan berapa lama waktu yang dibutuhkan untuk menyelesaikan tugas tersebut. Lebih jauh disebutkan bahwa orang dengan pertimbangan Efikasi Diri yang kuat mampu menggunakan usaha terbaiknya untuk mengatasi hambatan, sedangkan orang dengan Efikasi Diri yang lemah cenderung untuk mengurangi usahanya atau lari dari hambatan yang ada.

Dari beberapa pengertian di atas dapat disimpulkan bahwa Efikasi Diri adalah keyakinan individu dalam menghadapi dan menyelesaikan masalah yang dihadapinya di berbagai situasi serta mampu menentukan tindakan dalam menyelesaikan tugas atau masalah tertentu, sehingga individu tersebut mampu mengatasi rintangan dan mencapai tujuan yang diharapkan. 
Menurut Bandura (1997) perbedaan efikasi diri yang dimiliki setiap individu terletak pada tiga komponen, yaitu:

a. Dimensi tingkat kesulitan tugas (Level). Dimensi tingkat kesulitan tugas ini adalah dimensi yang berkaitan dengan tingkat kesulitan tugas yang dihadapi oleh individu.

b. Dimensi Generalisasi/keluasan

(Generality). Dimensi generalisasi berkaitan dengan luas cakupan bidang kemampuan yang dimiliki individu. Hal tersebut dapat dilihat dari kemampuan individu dalam mengerjakan tugas.

c. Dimensi tingkat kekuatan (Strength).

Dimensi tingkat kekuatan berkaitan dengan tingkat kekuatan dari keyakinan atau pengharapan individu terhadap kemampuannya.

Pilihan karir merupakan bagian dari kehidupan seseorang. Bahkan karir bagi sebagian orang dianggap sebagai status yang dapat menghidupkan atau mematikan seseorang. Karir pun berhubungan dengan stasus sosial seseorang. Menurut Super (dalam Hami, Hinduan \& Sulistiana, 2006), pengambilan keputusan karir terkait dengan ide dimana seseorang harus mengetahui bagaimana keputusan karirnya. Konsep ini menyangkut kemampuan menggunakan pengetahuan dan memikirkan rencana-rencana karirnya kedepan serta mampu mengambil keputusan.

Menurut Alwisol (2011) efikasi diri mengacu pada keyakinan yang berkaitan dengan kemampuan serta kesanggupan individu untuk mencapai dan menyelesaikan tugas-tugas dengan target hasil atau target waktu yang telah ditentukan.

Adapun hipotesis yang diajukan dalam penelitian ini yaitu ada hubungan yang positif antara Efikasi Diri dengan Pengambilan Keputusan Karir pada mahasiswa tingkat akhir Fakultas Psikologi Universitas Mercu Buana Yogyakarta.

\section{METODE}

Desain penelitian yang digunakan adalah desain penelitian korelasional yang pada dasarnya terdapat dua variabel, yakni variabel bebas dan variabel terikat. Variabel bebas (X) dalam penelitian ini adalah Efikasi Diri sedangkan variabel terikat (Y) adalah Pengambilan Keputusan Karir.

Efikasi Diri merupakan keyakinan individu dalam memperkirakan kemampuan dirinya untuk melakukan 
suatu tugas yang bertujuan mencapai hasil tertentu. Variabel efikasi diri diukur menggunakan skala efikasi diri yang disusun berdasarkan aspek-aspek Efikasi Diri menurut Bandura (1997), yaitu: level (tingkat kesulitan tugas), generality (keluasan), strength (kekuatan). Pengambilan Keputusan Karir dalah kemampuan mahasiswa dalam membuat pilihan karir dengan melihat kemampuan diri, lingkungan pendidikan atau pekerjaan, serta merencanakan langkah-langkah dalam rangka mencapai tujuan karir tertentu. Variabel pengambilan keputusan karir diukur menggunakan skala pengambilan keputusan karir yang disusun berdasarkan aspek yang dikemukakan oleh Milller dan Tiedeman, yaitu, Eksplorasi, Kristalisasi, Pemilihan, dan Klarifikasi.

Subjek penelitian dipilih secara purposive sampling. Subjek penelitian dalam penelitian ini adalah mahasiswa tingkat akhir Fakultas Psikologi UMBY Kampus 3, yaitu mahasiswa Semester 7 dan 8 (angkatan 2014/2015) yang berjumlah 50 subjek.

Pengumpulan data dalam penelitian ini dilakukan dengan menggunakan skala Efikasi Diri dan skala Pengambilan Keputusan Karir. Sebelum skala Efikasi Diri dan Pengambilan Keputusan Karir digunakan pada penelitian, terlebih dahulu diujicobakan pada sekelompok subjek untuk mengetahui nilai validitas dan reliabilitasnya. Uji coba skala dilakukan pada 50 mahasiswa Fakultas Psikologi Kampus 1 Universitas Mercu Buana Yogyakarta Angkatan 2014/2015. Padas kala Pengambilan Keputusan Karir, dari 40 aitem terdapat 31 aitem yang valid dan 9 aitem dinyatakan gugur. Koefisien validitas bergerak dari 0,326-0,723 dengan koefisien reliabilitas alpha $(\alpha)$ sebesar 0,916. Sedangkan untuk skala Efikasi Diri, dari 10 aitem, tidak ada aitem yang gugur sehingga semua aitem yang berjumlah 10 dinyatakan valid. Koefisien validitas bergerak dari 0,373-0,755 dengan koefisien reliabilitas alpha $(\alpha)$ sebesar 0,889 .

Data penelitian dikumpulkan dengan cara peneliti mengirimkan skala tersebut melalui Google Form kepada responden sehingga dapat lebih mudah dan cepat dalam pelaksanaannya. Untuk mengukur skala penilaian yang ada di dalam skala dengan menggunakan skala Likert. Alasan menggunakan skala Likert adalah untuk melihat data secara ordinal, untuk mengetahui penyebaran data pada responden. Teknik analisis data yang akan 
digunakan adalah uji statistik korelasi

Product Moment dari Karl Pearson.

\section{HASIL DAN PEMBAHASAN}

Hasil uji normalitas untuk data Pengambilan Keputusan Karir diperoleh nilai $\mathrm{KS}-\mathrm{Z}=0,808$ dengan $\mathrm{p}=0,532$. Berdasarkan hasil tersebut dapat disimpulkan bahwa data variabel Pengambilan Keputusan Karir mengikuti distribusi normal. Sedangkan data Efikasi Diri diperoleh nilai KS-Z $=1,187$ dengan $\mathrm{P}=0,120$. Berdasarkan hasil tersebut dapat disimpulkan bahwa data variabel Efikasi Diri juga mengikuti distribusi normal.

Hasil uji linieritas variabel Pengambilan Keputusan Karir dengan Efikasi Diri diperoleh F sebesar 2,684 (p < 0,01), yang berarti variabel Pengambilan Keputusan Karir dengan Efikasi Diri memiliki hubungan yang linier.

Berdasarkan hasil analisis korelasi terbukti bahwa ada hubungan yang positif antara Pengambilan Keputusan Karir dengan Eikasi Diri pada mahasiswa tingkat akhir Fakultas Psikologi UMBY dengan korelasi sebesar $\mathrm{r}_{\mathrm{xy}}$ 0,357 ( $\mathrm{p}<$ 0,05). Hal ini berarti bahwa hipotesis yang menyatakan ada hubungan antara Pengambilan Keputusan Karir dengan
Eikasi Diri pada mahasiswa tingkat akhir Fakultas Psikologi UMBY dapat diterima. Hubungan yang positif antara Pengambilan Keputusan Karir dengan Efikasi Diri pada mahasiswa tingkat akhir Fakultas Psikologi UMBY menggambarkan bahwa semakin tinggi Efikasi Diri maka akan diikuti dengan semakin tinggi tingkat pengambilan keputusan karir pada mahasiswa tingkat akhir Fakultas Psikologi UMBY.

Diterimanya hipotesis dalam penelitian ini menunjukkan bahwa efikasi diri dapat dianggap sebagai salah satu faktor yang turut menentukan pengambilan keputusan karir pada mahasiswa tingkat akhir Fakultas Psikologi UMBY. Hasil yang ditunjukkan dalam penelitian ini sejalan dengan penelitian yang dilakukan oleh Gilles dan Rea, yang membuktikan bahwa efikasi berperan penting dalam proses pengambilan keputusan terkait dengan karir seseorang. Betz dan Hacket menyebutkkan bahwa efikasi diri akan karir seseorang adalah domain yang menggambarkan pendapat pribadi seseorang dalam hubungannya dengam proses pemilihan dan penyesuaian karir (dalam Indarti \& Rostiani, 2008). 
Efikasi diri merupakan indikator yang penting dalam penentuan karir (Bandura, 1997). Hasil penelitian Budiningsih (2012) berhasil membuktikan bahwa efikasi diri mampu memprediksi pengambilan keputusan karir hingga sebesar 45,22\%. Hasil serupa juga ditemukan Widyastuti dan Pratiwi (2013), yakni efikasi diri lebih berpengaruh terhadap kemantapan pengambilan keputusan karir dibanding dukungan sosial keluarga, dengan kontribusi sebesar $30,8 \%$. Sebuah penelitian yang dilakukan oleh Fleming \& Barkin di Amerika Serikat (Ebtanastuti \& Muis, 2004) menunjukkan hanya $49 \%$ pelajar yang memiliki tujuan karir di masa depan. Penelitian yang dilakukan oleh Argyropoulou, Sidiropoulou-Dimakakou \& Besevegis (2007) di Yunani, menunjukkan hanya $40 \%$ pelajar yang sudah memiliki tujuan karir masa depan. Efikasi diri merupakan faktor penting yang menentukan perilaku pengambilan keputusan karir seseorang.

Pengambilan keputusan karir mahasiswa tingkat akhir di Fakultas Psikologi pada saat penelitian rata-rata berada pada kategori Rendah dengan jumlah sampel sebanyak 40 subjek atau $80 \%$. Kondisi ini berdasarkan gambaran umum skor variabel yang menunjukkan bahwa mean empirik variabel pengambilan keputusan karir 79,65 yang berada pada rentang 68 - 81 (kategori Rendah). Hasil tersebut menunjukkan bahwa mahasiswa Psikologi tingkat akhir kurang memiliki pemahaman yang baik akan dirinya, kurang mampu memahami akan tuntutan karir yang harus dipenuhi serta kurang memiliki kemampuan yang baik dalam melakukan penalaran akan kemampuan diri dan membandingkannya dengan tuntutan karir yang akan dipilih.

Efikasi diri mahasiswa tingkat akhir di Fakultas Psikologi pada saat penelitian rata-rata berada pada kategori Tinggi dengan jumlah sampel sebanyak 31 subjek atau $62 \%$. Kondisi ini berdasarkan gambaran umum skor variabel yang menunjukkan bahwa mean empirik variabel efikasi diri 79,65 yang berada pada rentang 31 - 40 (kategori Tinggi). Hasil tersebut menunjukkan bahwa mahasiswa Psikologi tingkat akhir (angkatan 2014) memiliki keyakinan yang tinggi bahwa mereka mampu dalam menghadapi dan menyelesaikan masalah yang dihadapinya di berbagai situasi serta mampu menentukan tindakan dalam menyelesaikan tugas atau masalah tertentu, sehingga mereka mampu mengatasi 
rintangan dan mencapai tujuan yang diharapkan.

Penelitian yang dilakukan oleh Peilouw dan Mursalin yang meneliti tentang hubungan antara pengambilan keputusan dengan kematangan emosi dan efikasi diri menunjukkan bahwa terdapat hubungan positif yang signifikan antara pengambilan keputusan dengan efikasi diri. Bandura berpendapat bahwa pengambilan keputusan karir dapat dipermudah atau diperlambat dengan efikasi diri. Menurut Noorderhaven terdapat faktor-faktor dalam diri individu yang dapat mempengaruhi pengambilan keputusan antara lain adalah: kematangan emosi, kepribadian, intuisi, dan usia (Peilouw \& Nursalim, 2013).

\section{KESIMPULAN}

Berdasarkan hasil penelitian, terdapat hubungan positif yang signifikan antara Efikasi Diri dengan Pengambilan Keputusan Karir pada Mahasiswa Tingkat Akhir di Fakultas Psikologi UMBY, sehingga hipotesis penelitian ini diterima. Efikasi diri yang tinggi pada mahasiswa dapat membuat mahasiswa memiliki tingkat pengambilan keputusan karir yang tinggi.
Efikasi diri merupakan kepercayaan seseorang atas kemampuan dirinya untuk menyelesaikan suatu pekerjaan. Efikasi Diri dapat berfungsi sebagai penentu beberapa hal, yaitu tingkah laku, pengeluaran dan ketekunan usaha serta pola pikir dan reaksi emosional. Efikasi Diri menentukan pemilihan tingkah laku atau aktivitas yang dilakukan individu. Individu cenderung menghindari tugas dan situasi yang dipersepsi melebihi kemampuannya (Ormrod, 2008). Pada penelitian ini, dapat disimpulkan bahwa mahasiswa yang memiliki tingkat efikasi diri tinggi akan memiliki tingkat pengambilan keputusan karir yang baik. Sebaliknya, mahasiswa dengan tingkat efikasi yang rendah, akan mengalami kesulitan dalam pengambilan keputusan karir.

Berdasarkan pembahasan dan kesimpulan, bagi subjek penelitian disarankan agar tetap memelihara, mempertahankan efikasi dirinya serta meningkatkan kemampuan yang berkaitan dengan pengambilan keputusan karir dengan cara mengikuti pelatihan untuk meningkatkan kemampuan serta mempertahankan keyakinan diri.

Bagi peneliti selanjutnya yang berminat untuk memperdalam topik yang 
sama dapat mengembangkan penelitian dengan memperluas orientasi kancah penelitian dengan mempertimbangkan faktor-faktor yang berkontribusi terhadap pengambilan keputusan karir, baik faktorfaktor internal maupun faktor-faktor eksternal.

\section{DAFTAR PUSTAKA}

Alwisol. (2007). Psikologi Kepribadian. Malang: Universitas Muhammadiyah Malang Press.

Argyropoulou, E.P., Sidiropoulou-Dimakakou, D., \& Besevegis, E. G. (2007). Generalized self-efficacy, coping, career indecision, and vocational choice of senior high school students in greece: implication for career guidance practitioners. Journal of Career Development, 33(4), 316-337.

Bandura, A. (1997). Social learning theory. New York: General Learning Press.

Bandura, A., (2002). Self-Efficacy - The Exercise of Control. New York: W.H. Freeman and Company

Budiningsih, T. E. (2012). Pengambilan keputusan terhadap perencanaan karir ditinjau dari efikasi diri dan ketepatan pilihan karir pada remaja SMA Negeri Kodya Semarang. Tesis (tidak dipublikasikan). Yogyakarta: Fakultas Psiko-logi Universitas Gadjah Mada.

Ebtanastiti, F.D. \& Muis, T. (2004). Survei pilihan karir mahasiswa Fakultas Matematika dan Ilmu
Pengetahuan Alam Universitas Negeri Surabaya. Jurnal BK. Volume 04 nomer 03 Tahun 2014. 1 -10 .

Hami, A.E. , Hinduan, Z., \& Sulastiana, M. (2006). Gambaran kematangan karir pada calon sarjana di lingkungan Fakultas Psikologi Universitas Padjajaran. Bandung: Fakultas Psikologi Universitas Padjajaran.

Indarti, N. dan Rostiani, N. (2008). Intensi Kewirausahaan Mahasiswa: Studi Perbandingan Antara Indonesia, Jepang dan Norwegia. Jurnal Ekonomika dan Bisnis Indonesia, Vol. 23, No. 4.

Ormrod, J.E. (2009). Psikologi pendidikan membantu siswa tumbuh dan berkembang. Jilid 2.Jakarta: Erlangga.

Munandir. (1996). Program Bimbingan Karier Di Sekolah. Jakarta: Departemen Pendidikan Dan Kebudayaan Direktorat Jenderal Pendidikan Tinggi Proyek Pendidikan Tenaga Akademik.

Peilouw, F.J, \& Nursalim, M. (2013). Hubungan antara Pengambilan Keputusan dengan Kematangan Emosi dan Self Efficacy pada Remaja. Character Vol 01 No 02 Hal:1-6.

Santrock. (2007). Adolescence Perkembangan Remaja: Edisi Keenam. Jakarta : Erlangga.

Sharf, R.S. (2006). Applying career development theory to counseling. California: Wadsworth, Inc. 
Syamsi, I. (2000). Pengambilan Keputusan dan Sitem Informasi. Edisi Kedua. Jakarta: Bina Aksara.

Widyastuti, R. J., \& Pratiwi, T. I. (2013). Pengaruh self efficacy dan dukungan sosial keluarga terhadap kemantapan pengambilan keputusan karir siswa. Jurnal BK UNESA, 3 (1), 231-238.

Winkell, W.S., \& Hastuti, S. (2004). Bimbingan dan konseling di institusi pendidikan. Yogyakarta: Media Abadi.

Badan Pusat Statistik. 2017. (https://www.bps.go.id/pressrelease/ 2018/05/07/1484/februari-2018-tingkat-pengangguran-terbuka--tpt-sebesar-5-13-persen--rata-rataupah-buruh-per-bulan-sebesar-2-65juta-rupiah.html, diakses tanggal 19 Maret 2017) 